\title{
MCCG 2012 versus MCCG 2017: Board Gender Diversity and Women CEO Issues within the Male-dominated Oil and Gas Industry
}

\author{
Dayana Mastura Baharudin (Correspondence Author) \\ Department of Accounting, School of Management \\ Universiti Sains Malaysia, Penang, 11800, Malaysia \\ E-mail: dayana.mastura@usm.my
}

\author{
Maran Marimuthu \\ Department of Management and Humanities \\ Faculty of Science and Information Technology \\ Universiti Teknologi PETRONAS, Tronoh, Perak, Malaysia \\ E-mail: maran.marimuthu@utp.edu.my
}

\begin{abstract}
Received: September 3, 2019 Accepted: October 20, 2019 Published: October 22, 2019
doi:10.5296/bms.v10i2.15290ＵRL: https://doi.org/10.5296/bms.v10i2.15290
\end{abstract}

\begin{abstract}
Purpose - This study investigates the impact of the two main determinants of strengthening the Board and Top Management Team through gender diversity contrasting between the pre and post MCCG 2017 era.

Design/methodology/approach - The study will employ the judgmental sampling method followed by descriptive statistics, regression analysis and quantitative content analysis derived from MCCG 2012 and MCCG 2017 as issued by the Malaysian Securities Commission together with prior research to analyse the annual reports in order to explore the reporting of gender diversity across the Board and Top Management Team.

Originality/value - This study is a systematic review of prior recent research developments in the Malaysian Securities Commission's MCCG 2012 and MCCG 2017. The Board of
\end{abstract}


Directors and Top Management Team scoring index could also be applied to other PLCs within the ASEAN oil and gas industry.

Keywords: Malaysian Code of Corporate Governance, MCCG 2012, MCCG 2017, Board Gender Diversity, Top Management Team Gender Diversity, Malaysian oil and gas industry

\section{Introduction}

Traditionally male-controlled oil and gas industry has not changed significantly, but that could change further as a result of the introductory Global Inclusion and Diversity report published by BP which is one of the leading global oil and gas firm together with Rigzone, a leading online oil and gas industry resource. Although almost three-quarters (72\%) of 3,000 petroleum and gas experts who participated in the research, stated that they believed that their sector was still male-dictated, $75 \%$ of respondents from the United States said that women's career prospects had improved in latest years, compared with $71 \%$ worldwide (Caldwell, 2018).

The study discovered that females willing to break into this industry are still facing some major obstacles. Participants have identified some of the most common problems, including gender discrimination, the lack of skilled applicants, the responsibility for family and social status. Managers looking to improve gender inequality in their oil and gas firms could consider providing flexible working agreements, child-care benefits, mentoring opportunities and pay transparency and formal policies for supporting women's representation (British Petroleum, 2018; Caldwell, 2018).

The training scheme also needs to contribute to having more female in the field of science, technology, engineering and mathematics (STEM). In fact, the findings of the 2012 International Student Assessment Program show that learners in the United States have been below the Organisation of the Economic Co-Operation and Development (OECD) average for advanced high school mathematics and science which is another additional barrier even not taking into account of female in STEM (Rigzone, 2018; Caldwell, 2018).

\section{Problem Statement}

Despite the excellent progress made over the last century towards gender equality, there are still many areas in which females are under-represented in the oil and gas industry. The Board of the Society of Petroleum Engineers (SPE) have thus given the consent of a new committee to address this critical problem. The Committee of SPEs Women in Energy (WIN) was established in 2016 and promotes gender diversity in the exploration and production (E\&P) industry, and with WIN part of a societal change, SPE members need to know some of the myths behind becoming leaders with a global transition to gender equality. WIN works to provide females engineers and oil and gas professional women with possibilities to become leaders and pursue their career objectives. The primary agenda of WIN is the development of a strong program to encourage diversity in the oil and gas sector, from entry through to retirement (Mounir, 2018). 
The charter of the WIN program aims to improve diversity from juniors to managers, attracting or employing females in the field of STEM, where SPE helps attract and educate young females in the areas of science, technology, engineering, and mathematics (STEM), through the work of the Energy4me program; female management or representation, to be involved with the Alliance of Emerging Leaders, to guarantee more variety of SPE-funded representatives and work with event committees to recognize more females during panel meetings, lectures and workshops during the choice of speakers ; initiatives from each SPE section or SPE chapters to hire leaders to represent WIN around the world and to concentrate on networking diversity activities and programs ; training and outreach to provide resources for WIN's Members and a large SPE community through partnerships with leading diversity professionals (Society of Petroleum Engineers, 2018).

Briefly, as females in the petroleum industry ascend the corporate ladder, SPE and WIN intends to assist individuals at all levels, cultures and languages in achieving their objectives. The main agenda of WIN is to promote more females to lead through SPE and to witness the growth of females to the development of incredible leadership. The energy sector is one of the most gender-imbalanced globally according to Forbes, in which it is regarded to be one of the industries with the smallest diversity. The complete talent of the population is not being used, so females are not at the decision-making level when it comes to taking the choices that would affect our world adversely as women's talents cannot be ignored (Mounir, 2018).

Therefore, this paper intends to investigate the evolution of gender diversity from the Malaysian Code of Corporate Governance (MCCG) 2012 era through to the era of MCCG 2017 across the Malaysian oil and gas industry focusing on the oil and gas public listed companies on Bursa Malaysia. The PLCs have been chosen specifically due to the size and the need to comply with the MCCGs as defined by the Malaysian Securities Commission.

\section{Research Objectives}

Following are objectives of the proposed study:

1. To measure the disclosure level of MCCG 2012 and MCCG 2017 on the Board Gender Diversity and Women CEO implementation within the Malaysian oil and gas industry.

2. To investigate the impact of the disclosure extent of Board Gender Diversity compared between MCCG 2012 and MCCG 2017 towards the financial performance of the Malaysian oil and gas PLCs.

3. To examine the impact of the disclosure extent of Women CEO compared between MCCG 2012 and MCCG 2017 towards the financial performance of the Malaysian oil and gas PLCs.

\section{Research Questions}

Following are the proposed questions of the study.

1. What is the disclosure level of Board Gender Diversity and Women CEO during the MCCG 2012 and the MCCG 2017 era which reflects the adherence level? 
2. Does the disclosure extent of Board Gender Diversity compared between MCCG 2012 and MCCG 2017 have impact on the financial performance of the Malaysian oil and gas PLCs?

3. Does the disclosure extent of Women CEO compared between MCCG 2012 and MCCG 2017 have impact on the financial performance of the Malaysian oil and gas PLCs?

\section{Literature Review}

The characteristics of top management (e.g. demographic) influence the decisions they make and therefore the actions taken by the organizations they lead. This occurs because demographic characteristics are associated with many cognitive bases, values and perceptions that influence decision-making at the top management level. Top management members could have a greater demographic diversity, influence the decision-making process in top management and make a positive contribution to strong performance (Marimuthu and Kolandaisamy, 2009).

Thus, the competitive behavior at the top level of the organisation could have a positive impact on firm results. In the case of BODs, diversity enhances higher creativity, innovation and quality decision-making, which is why this research expects a comparable strategic result, especially involving the boards of directors (Zahra \& Pearce, 1989), since boards are the most important players, boards are also responsible for the surveillance role of shareholders (Hambrick, 1996).

Research indicates that growing diversity on boards of directors would be useful to the organisation in terms of the acquisition of critical assets (Pfeffer \& Salancik, 1978) and, where corporate governance is concerned, advantages at the strategic stage are strongly linked to the varied top leadership (Eisendardt \& Bougeois, 1988). Occupational diversity among board members is also favorably linked to performance in the context of social obligations (Siciliano, 1996). Zander (1993) stresses that attempts must also be made to make the fullest possible use of the skills of the board members.

The Malaysian Code of Corporate Governance 2017 (MCCG 2017) states that in its Principle A, note 4.4 that Board appointments and senior management are based on objective criteria, merit and due regard for the diversity of abilities, experience, age, cultural background and gender. Furthermore, MCCG 2017 states that in Principle A, note 4.5, the Board discloses the policies of the company on gender diversity, its objectives and the measures to be taken to meet those objectives. For Large Companies, the Board must have at least 30\% female directors (Malaysian Securities Commission, 2017).

This is a step-up from the Malaysian Code of Corporate Governance 2012 (MCCG 2012) which did not specifically mention the minimum of $30 \%$ level of women directors.

\section{Theoretical Framework}

\subsection{Agency Theory}

In terms of the corporate performance and its basis on board structure, agency relationship plays a very significant part (Jensen and Meckling, 1976). Diverse boards can better monitor executives and leadership teams by increasing the board's independence (Hassan, Marimuthu 
and Johl, 2016; Carter et al, 2003). The Agency theory states that female directors behaves differently from their masculine counterparts and their presence changes the behavior of the board members as they are expected to deliver better monitoring, surveillance and consultation services (Azmi and Barrett, 2013). The company's reputation could be strengthened by having more females board of directors (Luckerath-Rovers and De Bos, 2011).

\subsection{Upper Echelon Theory}

Prior researchers asserted that diverse boards can make more efficient choices than homogeneous boards (Hambrick and Mason, 1984). Organizations may attract, maintain and compete with various talents by enhancing the diversity within the top leadership teams (Raver et al, 2005).

\section{Proposed Conceptual Framework}

\section{Diversity within the Board and Top Management Team}

\section{Firm financial performance}

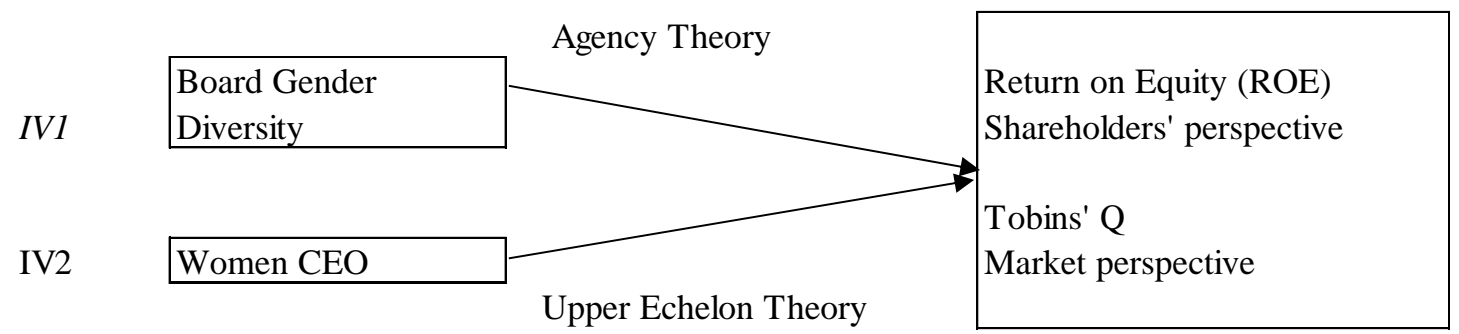

Dependent Variable

Figure 1. Proposed Conceptual Framework

\section{Dependent Variable - Firm Performance (Return on Equity and Tobin's Q)}

While the return on capital measures the return on all capital invested in the asset, the return on equity focuses solely on the equity element of the investment. It refers the income left over to equity investors after the cost of the debt service has been factored into the equity invested in the asset. As a result, the return on equity for a business is a composite return on all of its assets - money and operations. It is measured according to the following formula (Damodaran, 2007):

\section{Return on Equity $(\mathrm{ROE})=$ Net Income / Book Value of Equity}




\section{Macrothink

Tobin's q, identified as the capital market value of a company separated by the replacement value of its assets, is our dependent variable. Theoretically, $\mathrm{q}$ is a much more attractive metric than accounting return. By integrating a capital market measure of company rents, $q$ implicitly utilizes the right risk-adjusted discount rate, imputes balance yields and minimizes distortions owing to tax legislation and accounting conventions (Wernerfelt and Montgomery, 1988).

\section{Hypotheses of the Study:}

Hypothesis 1(a): Board Gender Diversity has positive impact on firm financial performance during the MCCG 2012 era.

Hypothesis 1(b): Board Gender Diversity has positive impact on firm financial performance during the MCCG 2017 era.

Hypothesis 2(a): Women CEO has positive impact on firm financial performance during the MCCG 2012 era.

Hypothesis 2(b): Women CEO has positive impact on firm financial performance during the MCCG 2017 era.

\section{Proposed Models for Future Empirical Testing}

In this context, and in line with the objectives of this study, the following models are proposed for future empiric tests:

\section{Model 1:}

$$
\mathrm{ROE}=\beta 0+\beta 1 B O D G E N D I V+\beta 2 W O M E N C E O+\text { eit }
$$

Whereas

ROE $=$ Return on Equity for measuring accounting performance of the Malaysian oil and gas PLCs (External perspective in terms of Shareholders)

TOBIN'S Q = the market value of a company divided by its assets' replacement cost. Thus, equilibrium is when market value equals replacement cost (External perspective in terms of Market)

BODGENDIV = Board Gender Diversity

WOMENCEO = Women CEO

cit $=$ Error term

\section{Model 2:}

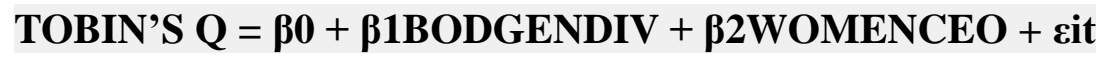




\section{Content Validity}

The parameters for the measurement of individual variables are chosen from the distinct measurement methods available in the Malaysian Code of Corporate Governance 2012 (MCCG 2012), the Malaysian Code of Corporate Governance 2017 (MCCG 2017) and the previous research in the Corporate Governance study.

\section{Scope and Methodology of the Study and Operationalization of Variables}

The study sample will be examined by analysing listed public companies publishing annual reports or integrated reports from the population of 900 Malaysian PLCs.

The data will be gathered from 2016 to 2018. A specific sample of 34 publicly listed oil and gas companies (PLCs) in Bursa Malaysia is suggested in this study. This study offers descriptive statistics, regression analysis and quantitative content analysis in the assessment of annual reports.

The year 2016 was selected because MCCG 2012 is still efficient and mature. The year 2017 was selected as the MCCG 2017 was launched this year and businesses are in the process of changing their corporate governance procedures from MCCG 2012 to MCCG 2017 and are most probable to have not yet implemented the modifications introduced in MCCG 2017.

MCCG 2018 was selected to see the impact of the modifications initiated in MCCG 2017 and to see that the new Code is likely to be implemented gradually. As a result, taking these 3 years will allow the investigator to differentiate between the pre-and post-effects of MCCG 2017.

Content analysis is the most commonly used technique for research and accounting disclosure (Zahid and Ghazali, 2015; Boesso and Kumar, 2007). The content analysis may have qualitative and quantitative measurements. Quantitative content analysis is regarded to be more reliable (Zahid and Ghazali, 2015; Day and Woodward, 2009). The present research will use the process of quantitative content analysis.

Data coding according to the content analysis technique would be based on topics, phrases or objects discovered in the information (Nilsson, 2016; Collins and Hussey, 2014).

Data coding according to the content analysis technique would be based on topics, phrases or objects discovered in the information (Nilsson, 2016; Collins and Hussey, 2014). During classification, a score scheme will be used to determine the extent to which items have been reported. The score scheme was based on a review of prior research that used content analysis to determine the suitable amount of points. Larsson and Ringholm (2014) and Eccles and Serafeim (2014) used a four-point scheme while Wang, Song and Yao (2013) used a three-point scheme.

Both Boiral (2013) and Setia et al. (2015) used two-point schemes. This study will use a scheme comparable to the earlier Nilsson Integrated Reporting studies (2016) to allow for some differentiation between businesses while still being a time-efficient technique. The 
scheme and criteria used in this research are shown in Table 1.

Table 1. A New Board of Directors and Top Management Team Diversity Scoring Index

Board of Directors and Top Management Team Diversity
$*>10 \%$ and $<20 \%$ Women Board of Directors and Top Management Team
$*>10 \%$ and $<20 \%$ Women Board of Directors and Top Management Team
$* 30 \%$ Women Board of Directors and Top Management Team
$*>30 \%$ Women Board of Directors and Top Management Team

\section{Significance of Study}

The suggested research is essential for publicly-listed businesses as it enables the annual report and integrated report preparers to recognize the significance of gender diversity and gender diversity at the top management team level for stakeholders and also for the use of inner planning in order to stay valid in the eyes of stakeholders and the general public. The application of the MCCG 2017 must be phased out in 2018 in order to guarantee the enhancement of corporate governance in the PLCs.

\section{Conclusion}

This study is restricted to only 1 year after the launch of MCCG 2017, which is 2018, in which future research could be undertaken to analyze the execution beyond one year of the application of the Code.

Alternatively, this study will be able to see any early implementation of the MCCG 2017 by big oil and gas PLCs in order to maintain corporate reputation in the context of gender diversity and gender diversity within the top management group.

\section{References}

Abdullah, S. N. (2013). The causes of gender diversity in Malaysian large firms. Journal of Management and Governance, 1-23.

Adams, R. B., \& Ferreira, D. (2009). Women in the boardroom and their impact on governance and performance. Journal of financial economics, 94(2), 291-309. https://doi.org/10.1016/j.jfineco.2008.10.007

Carter, D. A., Simkins, B. J., \& Simpson, W. G. (2003). Corporate governance, board diversity, and firm value. Financial Review, 38(1), 33-53. https://doi.org/10.1111/1540-6288.00034 
Co-operation, O. f. E., \& Development. (2004). OECD Principles of Corporate Governance 2004: OECD Publishing

Coles, J. L., Daniel, N. D., \& Naveen, L. (2008). Boards: Does one size fit all? Journal of financial economics, 87(2), 329-356. https://doi.org/10.1016/j.jfineco.2006.08.008

Gujarati, D. N. (2003). Basic Econometrics. 4th: New York: McGraw-Hill.

Hambrick, D. C., \& Mason, P. A. (1984). Upper echelons: The organization as a reflection of its top managers. Academy of management review, 9(2), 193-206. https://doi.org/10.5465/amr.1984.4277628

Hassan, R., \& Marimuthu, M. (2014). Gender Diversity on Boards and Market Performance: An Empirical Investigation on Malaysian Listed Companies. Platform - A Journal of Engineering, Science and Society, 10(1), 17-25.

Hassan, R., \& Marimuthu, M. (2016). Corporate Governance, Board Diversity, and Firm Value: Examining Large Companies Using Panel Data Approach. Economics Bulletin, 36, $1737-1750$

Hassan, R., Marimuthu, M., \& Johl, S. K. (2015). Demographic diversity and firm value: A review on large companies using panel data approach. Paper presented at the Technology Management and Emerging Technologies (ISTMET), 2015 International Symposium. https://doi.org/10.1109/ISTMET.2015.7359028

Hassan, R., Marimuthu, M., \& Kaur Johl, S. (2015). Diversity, Corporate Governance and Implication on Firm Financial Performance. Global Business and Management Research: An International Journal, 7(2), 28-36.

Hassan, R., Marimuthu, M., \& Kaur Johl, S. (2016). Women on Boards and Market Performance: An Exploratory Study on the Listed Companies. International Business Management, 10(2), 84-91.

Hausman, J. A. (1978). Specification tests in econometrics. Econometric: Journal of the Econometric Society, 1251-1271. https://doi.org/10.2307/1913827

Jensen, M. C., \& Meckling, W. H. (1976). Agency Costs and the Theory of the Firm. Journal of financial economics, 3(4), 305-360. https://doi.org/10.1016/0304-405X(76)90026-X

Lückerath-Rovers, M. (2013). Women on boards and firm performance. Journal of Management and Governance, 17(2), 491-509.

Marimuthu, M., \& Kolandaisamy, I. (2009). Demographic diversity in top level management and its implications on firm financial performance: An empirical discussion. International Journal of Business and Management, 4(6), 176. https://doi.org/10.1007/s10997-011-9186-1

Mitton, T. (2002). A cross-firm analysis of the impact of corporate governance on the East Asian financial crisis. Journal of financial economics, 64(2), 215-241. 
https://doi.org/10.1016/S0304-405X(02)00076-4

Monks, R., \& Minow, N. (2004). Corporate Governance, Vol. 3: Blackwell Publishing, Malden, MA.

Raver, M. J. G. J. L., \& Schneider, L. H. N. B. (2004). Discrimination in organizations: An organizational-level systems perspective. Discrimination at work: The psychological and organizational bases, 89.

Verbeek, M. (2008). A guide to modern econometrics: John Wiley and Sons.

\section{Copyright}

Copyright for this article is retained by the author(s), with first publication rights granted to the journal.

This is an open-access article distributed under the terms and conditions of the Creative Commons Attribution license (http://creativecommons.org/licenses/by/4.0/). 